\title{
Sergei Parajanov Speaks Up
}

\author{
By Ron Holloway
}

Spring 1996 Issue of KINEMA

\section{SERGEI PARAJANOV: INTERVIEW WITH RON HOLLOWAY}

This interview formed the basis of our documentary portrait, Parajanov, A Requiem (1994). The American spelling of "Parajanov" is used, instead of the British-French "Paradjanov," to differentiate this documentary from a dozen others made on the Armenia-Georgian director. The interview took place on 1 July 1988 in his hotel room on the morning before the world premiere of Ashik Kerib at the Filmfest München. Parajanov was always aware of the tasks facing the cameraman; accordingly, he would shorten or lengthen his answers to keep the interview flowing. His last speech on the stage of the Carl-Orff-Hall is added because be was actually speaking to the camera on this occasion.

Since Parajanov makes frequent references to his films, I have included a brief bio/filmography at the end of this interview. On occasion, I have inserted extra production dates, first names, and term explanations in the text to prevent needless reference delay. However, the reader should be aware that Parajanov often speaks in visual terms; thus, certain words -- artistismus," "pathology," "cardiogram," "biblical," "plastic" -have special meaning to him alone. Also, his references to the "Soviet Avant-Garde," "Socialist Realism," and "Socialist Neorealism" contradict definitions in both Soviet and Western film lexicons; in my opinion, his viewpoints are more accurate and reliable indices of the times.

Lastly, this interview was originally planned as the first half of a 90-minute documentary. The second half was to chronicle the shooting of Confession at his home in Tbilisi, a project he delayed until June of 1989, and then was not able to complete. We view this interview as complementary material to our 57-minute documentary on Parajanov, to which the subtitle A Requiem was added for the screenings at the Los Angeles and Venice film festivals.

Ron and Dorothea Holloway, Berlin, 8 December 1995

Holloway: Sergei, how did you become a film director?

Parajanov: I believe you have to be born a director. It's like a child's adventure: you take the initiative among other children and become a director, creating a mystery. You mould things into shape and create. You torment people with your "artistismus" - scaring mother and grandmother in the middle of the night. You dress yourself up like Charlie's Aunt, or as (Hans Christian) Andersen's heroes. Using feathers from a trunk, you transform yourself into a rooster or a firebird. This has always preoccupied me, and that is what directing is.

A director can't be trained, not even in a film school like VGIK (Soviet All-Union State School for Film Art and Cinematography). You can't learn it. You have to be born with it. You have to possess it in your mother's womb. Your mother must be an actress, so you can inherit it. Both my mother and father were artistically gifted.

\section{What was your diploma film at VGIK about?}

It was a short children's film: Moldavian Fairy Tale(1951). After (Alexander) Dovzhenko saw it, he said: "Let's see it again." For the first time in the history of VGIK, the examination board decided to watch a diploma film twice. (Rostoslav) Yurenev, now a successful film and art critic, said: "Parajanov has copied Dovzhenko. It is monumental and epic. Parajanov has seen Zvenigora(1928)."

Dovzhenko said: "You loudmouth! Sit down and listen to me. He hasn't seen Zvenigora." Then he said: "Where are you, young man?" I stood up, and he asked: "To tell the truth, have you seen Zvenigora?" I said: "No." "See, that's just nonsense!" Yurenev wasn't very well known at that time. He was a slim, slightly built young man, who ran from director to director.

Probably, my diploma film was pretty close to what I was prepared to bring to expression as a film director.

But your diploma film is lost...

No. It's at home. 


\section{Then why it isn't shown here in the retrospective?}

I simply forgot It. Only Andriesh, the longer version was shown here -- not to children, unfortunately, but to an adult audience.

What was it like in the courses conducted by Alexander Dovzhenko and Igor Savchenko?

Dovzhenko and Savchenko were enemies. They were always fighting, didn't get along. Both were talented, prominent, exceptional. One worked in the style of the Polish painter (Jan) Matejko, experimenting with Renaissance styles. The other depicted an apple, an old man death, a stork that comes and flies away -his art drew upon his epic childhood. And the clash of this aesthete with that archaic god-of-the-prophets provoked conflicts in Dovzhenko's studio.

Savchenko died young: he was only 43 years old. And lying in his coffin he looked like an old man. We have now survived him by 20 years. His students are older than their teacher was: (Vladimir) Naumow is 60 and I am 64. We've outlived him by 20 years. The loss of Savchenko grieved Dovzhenko to the depth of his soul. He took charge of our examinations and signed our diplomas. He was very generous. He was particularly enthusiastic about (Alexander) Alov and Naumov and the late (Felix) Mironer.

\section{It appears that VGIK was packed with talent at that time.}

There were several interesting people among us -- including, of course, Dovzhenko. I grieve for the dead, my fellow students. Four are no longer with us. We recently gathered together, set four empty plates on the table, like four candles, and thought of our friends who have left us: Alov, who spent his life filming with Naumov; Mironer, who made with (Marlen) Khutsiev Spring on Zarechnaya Street (1956); Grisha (Grigori) Aronov; and Seva (Vsevolod) Voronin. Four friends have left us, and who knows who will be next.

We were chosen by Savchenko, a gifted man. He loved and idolized us. And he inspired us. He waited for the day when we would perform a miracle. He was very happy when Khutsiev and Mironer signed a contract with GLKVK (Soviet All-State Film Distribution agency) for their first screenplay, Spring on Zarechnaya Street (1956). He drove with them in his "Mercedes" down Gorky Prospekt with the top down. They bought new socks, Khutsiev said. Savchenko made them take off their ragged socks, right there in the car. They threw them out of the car and put on new ones. Not only were they students, but filmmakers with money too.

Alov and Naumov co-directed Restless Youth (1958) and Pavel Korchagin (1957), also The Wind(1958). They pioneered the Avant-Garde.

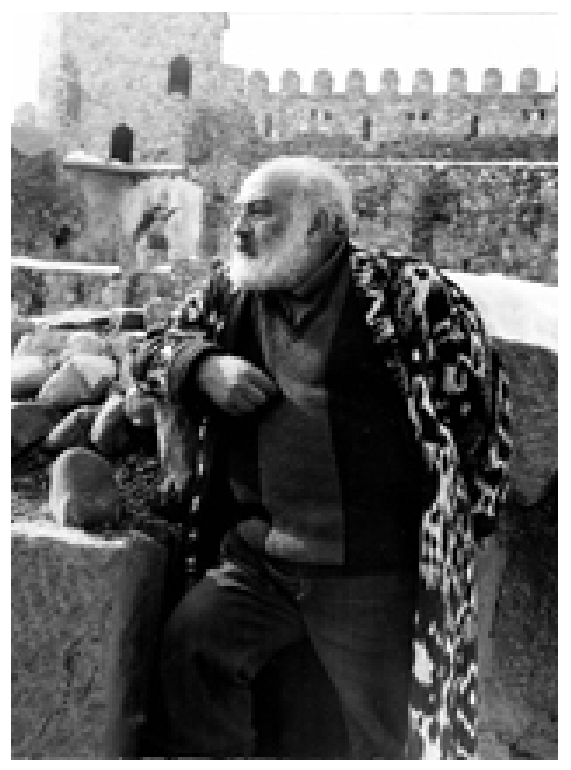

Figure 1: Director Sergei Parajanov

What is film direction for you? Real life? A dream? A mystery? Directing is fundamentally the 
truth as it's transformed into images: sorrow, hope, love, beauty. Sometimes I tell others the stories in my screenplays, and I ask: "Did I make it up, or is it the truth?" Everyone says: "It's made up." No, it's simply the truth as I perceive it.

\section{Your first films were made in a realistic vein. What made you change your style?}

I could work pretty much to my own satisfaction in those days. The times were realistic: the generation, the background, the canvas on which I worked.

I worked and suffered, under three despots. The despots were in the Kremlin. And today perestroika is seeking to become the cardiogram of the times. Perhaps, one day, a book will appear dealing with all those years, something like a cardiogram. As Stalin was on his way up, he lowered the price of socks. And people were content; socks were two kopeks cheaper. Every six months he would drop the price of socks and undershirts. But the price of bread didn’t change. A cardiogram...

The Soviet films of that era -- and not just mine -- are like a cardiogram of terror. They are cardiograms of fear. The fear of losing your film, the fear of starving. You feared for your work

\section{Are you a filmmaker? Or a graphic artist?}

I'm a graphic artist and a director who seeks to shape images. Savchenko, our mentor, encouraged us to sketch our thoughts -- and give them plastic form. We all had to draw our thoughts at the film school. For the entrance examination we were brought to a room and told: "Draw whatever you like..."

Are you pleased with the reception your graphic work received here at the Filmfest München? I'm very happy they are showing some of my work here in a workshop exhibition: my style of wall-exhibition, some wall-plates. I brought along about 20 works -- not very many, but enough to form an opinion. Among these is one with a bouquet of flowers, a collage dedicated to the mothers of Munich who lost their sons in the war. It's a bouquet of flowers placed upon a mirror -- a rather uncommon motif. For mothers who, like Soviet mothers, suffered terribly in the last war.

I'm taking some pictures, some really remarkable pictures, back home with me. I was invited to the Greek Orthodox (Ukrainian Uniate) church here in Munich. I attended the service and talked to the priest -- and on the wall of the clubroom they had a small exhibition of drawings by children. They had drawn the royal couple Prince Vladimir and Princess Olga. All the drawings dealt with this theme: wonderful, primitive drawings. They break the rules of Socialist Realism. Even Prince Vladimir is shown the way he was: lame and short-legged. They are delightful drawings. They are my best souvenirs from Germany, these children's drawings.

\section{What do you mean by "artistismus?"}

I can't help it: I idolize Lenin. As a director, I have to admire his artistismus: his artistic impulses, his abilities as a speaker. His brain was magnificent, gigantic like that of a prophet. The world wasn't large enough for him. His artistismus once compelled him to climb onto an armoured car, as if it were a stage. He stood there like a monolith; he was a born actor. I appreciate artistismus, artistic talent. Politicians, friends, anyone can have talent.

I don't like sleepy people. Brezhnev tried to act on my behalf, he tried to set me free, but he was asleep. We need gifted speakers. We like artistismus. We like politicians who speak without using notes. We like it when their wives stand by their sides. But certain circles dislike it if a woman stands at a politician's side. An intelligent and gifted woman. Our leaders were not used to that, they used to hide their wives away. These women were monsters, pathological monsters. I know what I am talking about.

Look how lovely and attractive the foreign minister's (Eduard Shevardnadze) wife is, although she's only present and never says a word. She comes from the Caucasus. This woman knows how to wear a hat. As a director I pay close attention to things like that. A hat is a sign of quality, of artistismus, an indication of artistic leanings. Above all, it's a sign of etiquette.

What does Socialist Realism mean to you?

Socialist Realism can't really be defined. It's not an encyclopedic concept. It exists only in our books. How can Socialist Realism be used as a label for films such as (Sergei and Georgi Vasiliev's) Chapayev (1934), for 
(Grigori Kozintsev and Leonid Trauberg's) The Youth of Maxim(1935) or The Vyborg Side (1939), for (Mark) Donskoy's Rainbow (1944) or She Defended Her Country (1945)? What about our stirring documentaries? Was that Socialist Realism? That was our film renaissance to shake the world!

But the Personality Cult put a halt to it. We had to extol to the heavens the imperium, the regime of the evil despots. Talented directors sold their souls making such films: (Mikhail Chiaureli's) The Vow (1946) and The Fall of Berlin (1949), were submissive works by court artists. The time has come to condemn them outright.

Why did Mikhail Chiaureli, who was recognized as an exceptional Georgian filmmaker, become Stalin's screen bard?

Some artists could sell themselves, as Chiaureli and (Vladimir) Petrov did. Others were in official positions. They were the "brain-power" people who filled offices, like (Mikhail) Bleiman and (Grigori) Zheldovich did. Although talented, they nonetheless ran our cinematography into the ground -- and our leading film personalities along with it.

So the great (Sergei) Eisenstein died with only an iota of his potential fulfilled. The great (Mikhail) Romm died, intimidated and shattered. Even Donskoy, the founder of the school of Soviet neorealism, who made Rainbow and The Unvanquished, could not develop his potential. That's a terrible tragedy.

Socialist Realism as a term is well known, but Soviet Neorealism? There are no books or journals or conferences dealing with those times. Everyone is silent. And it may all be forgotten by the next generation. Or an enthusiast will write about it, drawing upon this period in the archives. Should I ever open my own archive, you will find there three prison sentences stripping me of my freedom. And a court condemnation of me as a surrealist who sees the social structure as a chimera. As if I were a chimera perched on top of Notre Dame, with a huge snout and massive hooves, who looks out over the city of Paris. I was such a chimera, who looked out and envied the coming of a new day.

How many films did you make in the Ukraine?

I had made eight films in the Ukraine. My ninth film was Shadows of Our Forgotten Ancestors(1964). That's when I found my theme, my field of interest: the problems faced by the people. I focused on ethnography, on God, on love and tragedy. That's what literature and film are to me. After I made this film, tragedy struck.

What happened at the office of the Soviet film ministry when they saw Shadows of Our Forgotten Ancestors?

When officials saw the film, they understood it broke the principles of Socialist Realism and the social rubbish that ruled our cinematography at that time. But they could do nothing because it was too late: two days later, (Mikhail) Kotsyubinsky had his jubilee. It was his centenary. So they said: "Let him go ahead and show his film." The film was released. They could ban it later on. And then they would somehow be finished with the whole affair.

But when the intelligentsia saw it, they were moved. The film caused a chain reaction of unrest. The ministry asked me to make a Russian version. The film was not only shot in the Ukrainian language, but it was also in the Hutsul dialect. They asked me to dub the film in Russian. But I turned then down categorically.

Then you left the Ukraine to make Sayat Nova in Armenia...

I like that film very much. I am proud of It. In the first place, I am proud that it didn't win a Golden Lion or a Silver Peacock.

That's one thing. The other is that I had to make the film under the most difficult conditions. I had no technical pre-requisites, no Kodak material, no processing of the film stock in Moscow. I had absolutely nothing. I had neither enough lighting, nor a wind-machine, nor any possibility for special effects. Nevertheless, the quality of the film is indisputable.

The results were the appearance of a primitive realistic milieu, like in a typical village or the average steppe. Little turkeys made to look like little turkeys... a fairy tale moulded from a real situation... different ways to give the impression of "hyper-realism." If I needed a tiger, then I would make a tiger out of a toy -- and 
it would have more effect than a real tiger would have. A rag tiger to frighten the hero would be more interesting.

\section{Would you agree that Sayat Nova (1966) is a "film of the Caucasus?"}

I think Sayat Nova is like a Persian jewelry case. On the outside its beauty fills the eyes; you see the fine miniatures. Then you open it, and inside you see still more Persian accessories.

It's like this: My hero's mother made 15 Kurdish skirts for us. She's a Kurd who works, who clears the streets, who works as a housekeeper. These frilled skirts are first drawn over the head and then draped over the arms. The effect is like a Pasolini film. I don't want to hide that, I want to underscore it.

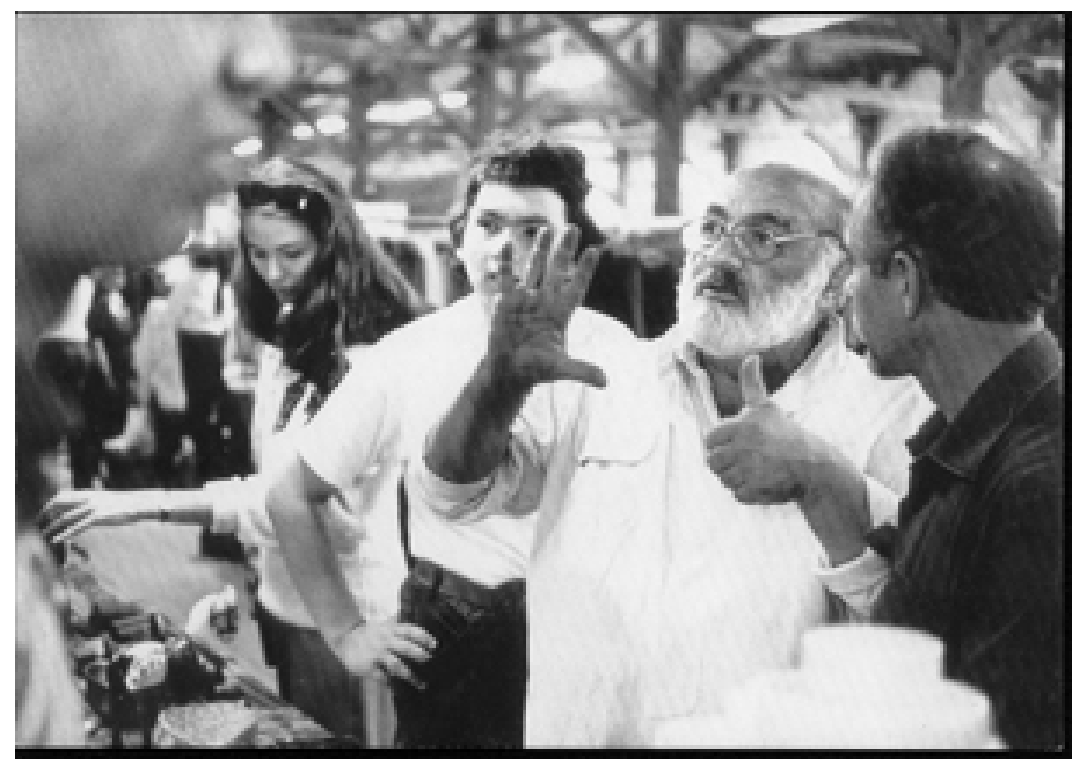

Figure 2: Sergei Parajanov in the documentary Parajanov - a Requiem

Your Sayat Nova does appear to have been influenced by Pasolini. Many like to imitate whatever is fashionable. But as soon as they begin to imitate something, it turns out that they are poor and miserable creatures reduced to beggary.

However, one does follow in another's footsteps. If someone said: "Your films resemble those of Pasolini," then I'd feel larger than life. I could breathe easier. For Pasolini is like a god to me, a god of the aesthetic, master of style, one who created the pathology of an epoch. He surpassed himself in costumes; he surpassed himself in gestures. Look at his Oedipus Rex (1967). I believe it's an absolutely ingenious work. His actors, his feeling for femininity, for masculinity..

Pasolini is not just a god. He is closer to God. He's also closer to the pathology of our existence on earth, to our generation. I have just seen his 1001 Nights (1974). For me, this is a powerful interpretation of the bible. It's struck from the same composition, moulded from the same plastic form, as found in the bible.

\section{Do you admire Fellini's films?}

The magic in Fellini's films surprises. His incredible gift for fantasy is astonishing. But it only goes in one direction -- towards mystification. He possesses a headstrong passion to make his characters larger than life. Look at his E la nave va (And the Ship Sails On, 1984), a great film about the tragedy of time... about an opera singer (Edmea Tetua)... about war (World War One). Everything happens on the deck of a ship: this dispersing of the ashes of a famous singer from La Scala -- ingenious! How can people say he's burnt himself out? On the contrary, it's one of Fellini's best films. Look at his Casanova (1976)!

Is the national, ethnographic character of your films after Shadows of Our Forgotten Ancestors what got you in trouble with the authorities?

Nature delivers us, and she takes us back to her bosom. You have to worship nature: her truth, her ideal, her 
motherhood, her homeland. Nature crates both patriotism and fanaticism, in order to defend the principles of its government, to love a country with tenderness.

I was an Armenian in the Ukraine, dealing with Ukrainian issues. I was awarded 23 gold medals for Shadows of Our Forgotten Ancestors -- the first in Mar del Plata, the last in Cádiz. I was known and recognized in the Ukraine. The Ukrainians loved me. My wife was Ukrainian, my son was Ukrainian. But this was not liked in certain circles. I was arrested and imprisoned for five years. A harsh sentence.

\section{What happened in prison? How did you manage to survive?}

The isolation in the prison camps of the Soviet Union was hard to bear. But the real tragedy was that I could have gone to pieces and lost my profession. I could have become a criminal in this milieu. There were prisoners with long criminal records, backsliders, dangerous people. I fell into this milieu, and then my art saved me. I began to draw. After four years and eleven days, I was released. Thanks to Louis Aragon and Elsa Triolet, to my good friend Herbert Marshall, to John Updike, I gained my freedom. I was pardoned eleven months and 18 days before serving the full sentence.

Besides that, the prisoners liked me, I took up the mission of hearing their confessions. Each criminal's confession, the tragedies and crimes whispered in my ear, was like a great screenplay or a great novella. They are presents given to me. I received a hundred novellas and six screenplays -- four of which will be filmed in the near future. The rest remains my secret. They may be published someday, they may appear upon the screen, or they may be buried with me forever.

The time in prison was hard. But instead of falling apart, I left the prison richer as the author of four screenplays. One of these is going into production. The director (Yuri) Ilyenko will film Swan Lake -- The Zone (1990), my screenplay about the backsliders' milieu. It's about the criminal milieu and its pathology, the isolation that makes people pathological. They lock you up for ten days, and you become pathological, mentally and sexually, just to survive. Because isolation is gruesome. If you put 2,000 people in isolation in a prison camp, in a "zone," tragic things happen. Tragic situations and pathologies.

\section{So what did you do?}

I began to draw. I turned to graphic art. I created and brought back with me some interesting material, drawings which I created in this isolation. And my friends believe that in the midst of all that filth I achieved an amazing purity in my work, and in my spirituality.

When I fell into the worst possible prison conditions, I understood I had a choice: either I would go under, or I would become an artist. So I began to draw. I brought with me out of prison 800 works. Much of my prison work was recently exhibited in Yerevan. The exhibition ran for three months. On May 15, when the exhibition closed, there was a queue a kilometre long.

Your last film, Ashik Kerib, is a children's film -- like your first, Andriesh.

Yes, Andriesh stands very close to Ashik Kerib. But they're different. It's a question of know-how, of experience, of the times. Back then, there was the innocence and the flame of youth. I had to make Andriesh in a hurry.

\section{How did Ashik Kerib come about?}

When I was seven years old, I was sick with angina and my mother read to me Ashik Kerib, a fairy tale by (Mikhail) Lermontov. It's not very well known; they don't treat it at school any more. A Turkish woman in the Caucasus told this fairy tale to Lermontov, who was as great a poet as (Alexander) Pushkin. Lermontov moved me deeply when I was a child. I remember I cried. I cried because Magul Migeri was waiting for her beloved. She had to marry another man and wanted to kill herself. She exposed herself to sword and poison not to betray her love. But then Ashik returned. It ends like an American movie: it has a Happy End.

I began looking for my Ashik Kerib, this Muslim minstrel who wanders around the world to earn enough money to buy Magul Migeri's freedom. I found just such a young man, a Kurd, my neighbour. At 22, he was a ruffian: he beat up a policeman. He thrashed a caretaker because of a leaky roof. He stole cars and got into brawls, then I met him, I asked: "Can you quit being a ruffian for a year?" He said; I can quit forever, it all depends on what you offer." Kurds are not Muslims. He's a Christian, but he plays a Muslim on the screen. 
The music is remarkable in Ashik Kerib...

It's Muslim music. It's not music from the Trans-Caucasus. It's the Muslim muram, an ancient rhapsody song. A Muslim minstrel tramps around the world, singing rhapsodies. The Muslim comes to the Christian world, to Georgia, in the episode called "The Ruined Cloister." Here's the idea of a "God Is One" -- there's only one God. That's the meaning of the Georgian leitmotif: the Georgian choir, the Georgian children who rescue him from his own kind when he's being beaten by Muslims to prove that "in the land of the enemy you're the enemy." Perhaps you're our brother who's trespassing the land of the enemy, but that makes you our enemy. Essentially that's what the music conveys.

I hired a talented Azeri composer. His name is (Lavanchir) Kuliyev. He understood what I wanted. The wok was very challenging. I presented him with a number of difficulties but he mastered them all. We even used European music: an "Ave Maria," Schubert, Gluck, motifs from the "Passion." The music flowed beautifully, giving it a modern touch. We wanted European audiences to link the "Ave Maria" with the Muslim world.

But I thought I also heard church music in the film score...

Yes, organ music, Christian church music. It's in the episode "God Is One" -- in Georgia, where multi-chord a cappella church music is heard. The rest is Muslim muram. Whether the public will understand the film is something else again. Children from an orphanage sing in the film. Children come to a school from the provinces, from the mountains, from the steppes, just to learn how to sing the muram. Singing children can add emotional depth to a film.

Only a few films stride the border between two worlds, and only a few directors. Yilmaz Güney was one of them. It is astonishing how he, someone from the East, could make films for Europe. This culture straddles the border between the Orient and the Western World.

Do your last three films -- Sayat Nova, The Legend of Suram Fortress, and Ashik Kerib -form a trilogy, thematically or stylistically?

You tie together films into a trilogy in order to win a Lenin Prize -- and enjoy public acclaim! This happened to (Tengiz) Abuladze and his three films: his outstanding Prayer (1969), The Wishing Tree (1977), and Repentance (1986) -- but they are not really connected at all. They have nothing in common. They were linked together as an excuse to award him the Lenin Prize. They tied them together because of their similar styles, because of their graphic strength of expression.

I don't need that kind of superficial tribute. My films have only one thing in common: a similarity in style. My life is testimony enough. I didn't want to found a school or teach anyone anything. Whoever tries to imitate me is lost.

We have an army of talentless young directors, young parvenu types, who come to the cinema and wait to become directors. Rather, they should consider how they can become a director for a lifetime.

You've been planning your new film, Confession, for a long time. I owe Armenia a cinematographic confession, a sort of personal bible. It's about my mother, my father, my childhood, my isolation in prison, my vision of dreams. And the tragedy of a cemetery being torn up to allow for a cultural park in honour of (Sergei) Kirov. The cemetery must give way to honour the Communist Kirov. The Soviet patriot arrives, and the ghosts are cast out. They don't know where to go, so they seek shelter with me, their living heir. But I can't take them in. I'm obliged to report to the local police that they are spending the night with me. I, who have no electricity, who is not an insurance agent. They know no evil. Their generation, back then, was kinder. They only want to stay with me. And I must die before their eyes to prove I love them.

It's my duty to my people. I am an Armenian from Georgia. I've made films in the Ukraine. I've suffered behind bars in Georgia and the Ukraine. Sometimes I wake up at night, and I imagine I am being attacked by lice. You may enter prison clean, but they swarm all over you. Within two hours you are covered with lice.

What are you planning to make next? A film on Faust?

Yes, but before I make a film on Faust, I would like to go to America to make a film on Longfellow's The Song of Hiawatha.

It's a great work. It is still widely known in Russia to our generation. But it's hard to find a translation of 
the book; unfortunately, no one takes the trouble to reprint it, I want to shoot it in America, against the landscape found in Longfellow. I need nature, Indians, feathers, horses, brown-skinned maidens, handsome heroes. In America it can be filmed quickly and for very little money. A clever producer would know where the possibilities lie, how to make good contacts, Nature takes care of the rest. Nature has already created a lovely set, and Hiawatha costumes already exist. I have only to determine the number of feathers for the chief's costume. My film would be a kind of biblical tale, The Song of Hiawatha is a variation on the biblical theme. Ashik Kerib is also a Muslim biblical variation with regard to the hero's attitude towards nature, humour, women, evil, and beauty.

\section{And Faust?}

Faust is the issue for Germany, for the governments in East and West Germany, in the GDR and the FRG. I believe the Germans are a great people. Despite the wall separating them, they share the same history, and a common future. I hope the film will be well thought out. It shouldn't be viewed as a commercial project. The film should be made for its artistic value.

Faust is important for the coming generation. The current generation can't be re-educated. TV rules their lives; they like to chew gum; they wear certain clothes. But the next generation will do without all this. We artists, directors, politicians, must ensure the upbringing of the coming generation. And the Germans of tomorrow are still in the womb. They, the "little Germans," need Faust if they are to grow up to become "great Germans."

\section{Why did you choose the Filmfest München for the premiere of Ashik Kerib?}

I would rather show Ashik Kerib to the public in Munich than anywhere else.

I have something important to say about my film. I like this film very much. Every artist must know when he will die. I would like to die after this film because I am very proud of it. This film is dedicated to the memory of my friend Andrei Tarkovsky. God Is One... I would like to request a minute's silence in memory of the director Andrei Tarkovsky.

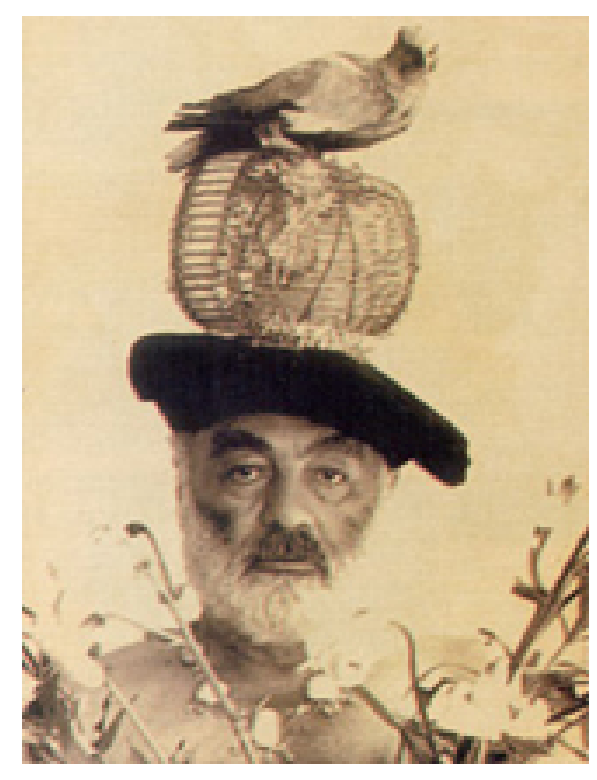

Figure 3: Director Sergei Parajanov

\section{References}

\section{Sergei Parajanov Bio/Filmography}

Born Sarkis Yossifovich Paradjanian of Armenian parents on 9 January 1924 in Tbilisi, Georgia, Sergei 
Parajanov transferred from the Tbilisi Institute for Railway Engineering (1942) to study song and violin at the Tbilisi Conservatory of Music (1943-45) before gaining admission to VGIK, the Soviet All-Union State School for Film Art and Cinematography (aka Moscow Film School) in 1946. He graduated as a film director in 1951 under the tutelage of Ukrainian directors Igor Savchenko and Alexander Dovzhenko and found employment at the Kiev Film Studios (later renamed the Alexander Dovzhenko Studios).

Parajanov began his career by making the same film twice and with the same co-director, Yakov Brazelian. Shortly after completing their diploma film, Moldavian Fairy Tale (1951), shot in the Ukraine, he assisted his mentor Igor Savchenko on Taras Shevchenko (1951) and then remade with Brazelian their graduation short as a feature-length children's film titled Andriesh (1955). Moldavian Fairy Tale appears to be lost, although Parajanov claimed to have kept a copy at his home in Tbilisi. Three documentary films followed: Ballad(1957), about a choral group and made for the anniversary of the 1917 Revolution; Golden Hands (1958), about folk art and co-directed with two other documentary filmmakers; and Natalya Ushviy (1959), a portrait of a prominent Ukrainian stage and screen actress. All three documentaries can be found in the Kiev archive. His next three feature films at the Dovzhenko Studios -- The First Lad (1959), Ukrainian Rhapsody(1961), and The Flower on the Stone (1962) -- generally followed the prescribed principles of Socialist Realism, yet each did contain scenes that went against its grain.

Parajanov's ninth film in Kiev, Shadows of Our Forgotten Ancestors (1964), caused an uproar by smashing to bits the principles of Socialist Realism in Soviet cinema. Although awarded at several international film festivals, it was given only limited release in the Soviet Union. In trouble with the authorities for also protesting the arrest of Ukrainian poets and intellectuals, Parajanov accepted an offer from Yerevan to make a documentary on Akop Ovnatanian (1965), an Armenian portrait painter who had lived and worked in Tbilisi. Portraits by Ovnatanian were later incorporated into scenes in Kiev Frescoes (1966), a production interrupted at the Dovzhenko Studios after a fen weeks of shooting. Only fragments of Akop Ovnatanian and Kiev Frescoes remain today. The same fate befell Sayat Nova, shot under primitive conditions in Armenia. When the director's cut was confiscated, Sergei Yutkevich cut 20 minutes out of the original in an effort to save the film and re-edited the remainder into The Colour of the Pomegranates (1969) for limited Moscow release. "My masterpiece no longer exists" (Paradjanov) -- although an attempt has recently been made in Armenia to reconstruct the original version.

All further attempts to make a film proved in vain. After years of intrigue and suspicion, Parajanov was arrested in Kiev on 17 December 1973 and, after a court hearing, sentenced on 25 April 1974 to five years imprisonment at the Dnepropetrovsk camp for hardened criminals. The charges were given as "business with art objects," "leaning towards homosexuality," "incitement to suicide," and "black-marketing." In 1978, as the result of world-wide protests and petitions made by friends and artists, he was released and allowed to return to his family home in Tbilisi, but not permitted to find work in a film studio. On 11 February 1982, he was arrested again by the KGB, "for bribing a public official" to help a nephew gain entrance to the university, and detained in the Voroshilovgrad prison until November 1982.

After 15 years on a blacklist, Parajanov received the support of Eduard Shevarnadze, First Secretary of the Georgian Communist Party, to make the feature The Legend of Suram Fortress(1985), co-directed by actor Dodo Abakhidze, and the documentary Arabesques on the Theme Pirosmani (1986) at the Gruziafilm Studio in Tbilisi. His last film, Ashik Kerib (1988), a Georgian-Armenian-Azerbaijan co-production, has received limited release in these countries. On 4 June 1989, he began shooting the first scenes from his autobiographical film, Confession, at his family home in Tbilisi. Three days later, he was taken to a hospital with respiratory problems. An operation for lung cancer in Moscow followed, then radiation treatments in Paris. Sergei Parajanov died on 20 July 1990 at the age of 66 in Yerevan, where he is buried.

\section{Author Information}

Ron HOLLOWAY (1933-2009) was an American critic, film historian, filmmaker and correspondent who adopted Europe as his home in the early fifties and spent much of his life in Berlin. He was an expert on the study of German cinema and against all odds produced, with his wife Dorothea, the journal German Film, 
keeping us up-to-date with the work of directors, producers and writers and the showing of German films around the world.

In 2007, Ron Holloway and his wife were awarded the Berlinale Camera Award. Ron also received the Bundesverdienstkreuz (German Cross of Merit), Polish Rings, Cannes Gold Medaille, the American Cinema Foundation Award, the Diploma for Support of Russian Cinema and an honorary award from the German Film Critics' Association.

Ron was also a valued contributor to Kinema for the past fifteen years. 